\title{
MENEROPONG PEMIKIRAN MARK JUERGENSMEYER TENTANG IDENTITAS AGAMA ANTI GLOBAL
}

\author{
Oleh:
}

Sun Choirol Ummah, M.S.I. sunchoirolummah@uny.ac.id

\begin{abstract}
Abstrak
Agama antiglobal dalam cermatan Mark Juergensmeyer merupakan perwujudan dari gerakan dalam agama yang anti-Westernisme. Gerakan agama ini membenci modernitas ala Barat jenis apa pun, baik dalam eksploitasi ekonomi, politik, maupun budaya. Anehnya, gerakan agama ini skeptis dalam memandang modernisme, sekularisme, dan individualisme. Gerakan ini justru mengadopsi teknologi dan sistem moneter modern ala Barat. Tidak hanya itu, gerakan ini juga mengklaim bahwa nasionalisme religious di negara-bangsa modern merupakan ide bentukannya. Pada kenyataannya, gerakan agama ini justru mengalami kerancuan dalam memahami antara konsep westernisasi, modernisasi dan globalisasi, hingga seolah ia kehilangan identitas dirinya. Identitas agama dianggap penting karena menjadi spirit, dasar pijakan, visi, dan misi sebuah gerakan.
\end{abstract}

Kata kunci: agama antiglobal, identitas, modernitas

\begin{abstract}
The antiglobal religion in Mark Juergensmeyer's view is the embodiment of the antiWesternism movement. This religious movement hates any kind of Western-style modernity, both in economic, political and cultural exploitation. Strangely, this religious movement was skeptical in viewing modernism, secularism and individualism. This movement actually adopted technology and a modern Western-style monetary system. Not only that, this movement also claimed that religious nationalism in the modern nation-state was an idea formed. In fact, this religious movement actually experienced confusion in understanding between the concepts of westernization, modernization and globalization, until it seemed that it lost its identity. Religious identity was considered important because it became the spirit, foundation, vision and mission of a movement.
\end{abstract}

\section{PENDAHULUAN}

Serangan udara spektakuler 16 tahun yang lalu di World Trade Center (WTC), New York tepatnya pada 11 September 2001 menjadi titik sentral para demonstran al-Qaeda pimpinan Osama bin Laden. WTC bukan hanya sebuah simbol kekuatan Amerika, melainkan juga sebagai pusat perdagangan dunia dan tanda kekuatan ekonomi global. Dikendalikan dari menara kembar yang tinggi di atas Manhattan Wall Street, jaringan ekonomi benar-benar memiliki jangkauan global. Hampir setiap pusat 
keuangan utama dunia diwakili di kantor WTC yang karyawannya datang dari setiap penjuru dunia.

Dalam daftar jenazah yang dihitung setelah runtuhnya bangunan WTC, di antara para korbannya terdapat sekitar 86 warga negara yang berbeda. WTC dipilih al-Qaeda sebagai target kedua setelah serangan bom pertama pada Pebruari 1993 kurang berhasil. Asumsi yang mudah ditebak yakni terjadinya perang agama. Di lembar lainnya, asumsi sangat bervariasi, di antaranya keberatan bin Laden pada nilai-nilai sekuler Barat, militer Amerika, agresifitas ekonomi modern, kecaman terhadap Arab Saudi dan Muslim moderat lainnya sebagai boneka Amerika, dan Pentagon maupun WTC yang mewakili kekuatan Amerika atas militer dan ekonomi (Juergensmeyer, 2005: 137).

Islam militan yang terkait dengan jaringan al-Qaeda menunjukkan bahwa tatanan baru dunia Barat yang didominasi globalisasi ekonomi merupakan musuh utama al-Qaeda. Serangan terhadap WTC merupakan luapan kebencian terhadap globalisasi oleh jenis tertentu yang dalam bahasa Juergensmeyer “jenis tertentu” ini dimaksudkan sebagai jaringan modern dan transnasional al-Qaeda yang menggunakan caranya mereka sendiri. Anggota al-Qaeda sangat profesional, canggih, memiliki teknisi yang terampil dan pengikutnya dari berbagai bangsa yang mudah berpindah dari satu tempat ke tempat lainnya tanpa loyalitas nasionalis yang jelas. Artinya, mereka tidak menentang globalisasi selama itu desain mereka sendiri.

Gerakan al-Qaeda antiWesternism ini membenci modernitas ala Barat jenis apa pun yang menekan mereka, baik eksploitasi ekonomi, politik, maupun budaya. Anehnya, mereka skeptis dalam memandang modernisme, sekularisme, dan individualisme. Mereka mengadopsi teknologi dan sistem moneter modern ala Barat. Tidak hanya itu, mereka juga mengklaim bahwa nasionalisme religius, negara-bangsa modern merupakan ide mereka. Ambivalensi ini menggelitik Juergensmeyer untuk mempertanyakan, apakah modernitas Barat itu selalu jahat dan modernitas atau postmodernitas itu sebanding dengan globalisasi? Di satu sisi, gerakan anti-Westernism ini merupakan reaksi atas globalisasi budaya Barat dan sisa-sisa kolonialisme. Di sisi lain, gerakan-gerakan keagamaan menunjukkan alternatif modernitas dengan aspek internasional dan supernasional dari mereka sendiri. Ini 
berarti bahwa di masa depan bentuk politik agama bersifat global, antiglobal, atau menciptakan alternatif negarabangsa sendiri. Tulisan ini bermaksud melacak akar motif agama yang antiglobal melalui salah satu karya Juergensmeyer Religion in Global Civil Society (2005).

\section{PROFIL}

\section{MARK JUERGENSMEYER}

Berdasarkan informasi dari laman jurnal the Departement of Global Studies Santa Barbara, California yang dipublikasikan tahun 2016 dengan website http://www.juergensmeyer.org/ dipaparkan bahwa Mark Juergensmeyer merupakan profesor yang berkecimpung dalam bidang studi kawasan global, profesor dalam ilmu sosiologi, pernah menjabat sebagai ketua di Kundan Kaur Kapany dalam Studi Global dan Sikh, dan profesor ilmu agama di Universitas California di Santa Barbara. Dia juga sebagai pendiri sekaligus sebagai direktur pada program studi Global dan International pada Pusat Studi Global dan Internasional Orfalea. Dia juga seorang pakar kekerasan dalam agama, resolusi konflik, dan pakar di bidang agama dan politik Asia Selatan. Di samping itu dia telah menerbitkan lebih dari dua ratus artikel dan dua puluh buku, termasuk ikut menulis dalam God in the Tumult of the Global Square: Religion in Global Civil Society bersama Dinah Griego dan John Soboslai (Universitas California Press, 2015).

Karyanya yang tersebar luas di antaranya Terror in the Mind of God: The Global Rise of Religious Violence (University of California Press, edisi keempat yang terbit tahun 2017), didasarkan pada wawancara dengan aktivis agama di seluruh dunia termasuk aktivis Jihad, pendukung ISIS, para pemimpin Hamas, dan pebom klinik aborsi di Amerika Serikat yang pada edisi sebelumnya didaftarkan oleh Washington Post dan Los Angeles Times sebagai salah satu buku nonfiksi terbaik tahun itu. Edisi pertama dari buku yang berjudul Global Rebellion: Religious Challenges to the Secular (University of California Press 2008) disebut oleh New York Times sebagai salah satu buku terkenal tahun itu.

Bukunya tentang resolusi konflik Gandhi telah dicetak ulang dengan judul Gandhi's Way (University of California Press, edisi diperbarui, 2005), dan terpilih sebagai Community Book of the Year di University of California, Davis. Dia bersama-sama 
Jurnal Humanika, Th. XVII, No. 1. Maret 2017

dengan Saskia Sassen dan Manfred Steger menulis buku The Oxford Handbook of Global Studies (Oxford University Press, yang terbit tahun 2017 dan Victor Faessel sebagai editor).

Di samping itu, ia mengedit buku Thinking Globally: A Global Studies Reader (University of California Press, 2015 ), oxford Handbook of Global Religion (Oxford University Press 2006) dan Religion in Global Civil Society (Oxford University Press 2005), dan menyunting The Encyclopedia of Global Religions (disunting bersama dengan WC Roof, Sage Publications 2008) dan The Encyclopedia of Global Studies (bersama Helmunt Anheier, Sage Publications 2009).

Juergensmeyer telah menerima beasiswa penelitian dari Center Wilson di Washington D.C., Yayasan Harry Frank Guggenheim, Institut Perdamaian A.S., dan Dewan Persatuan Ilmu Pengetahuan Amerika. Dia sebagai penerima Penghargaan Grawemeyer bergengsi untuk kontribusi studi agama, dan dianugerahi Silver Award oleh Ratu Sofia untuk pusat studi Kekerasan Agama di Spanyol. Dia menerima Doktor Kehormatan dari Universitas Lehigh dan Universitas Roskilde di Denmark, sebuah Penghargaan
Pengajaran yang terhormat dari University of California, Santa Barbara, dan Unitas Distinguished Alumnus Award dari Union Theological Seminary, New York. Dia terpilih sebagai presiden American Academy of Religion, dan memimpin kelompok kerja untuk Agama dan Urusan Internasional pada Dewan Riset Ilmu Pengetahuan Sosial nasional yang menghasilkan jurnal Rethinking Secularism (disunting bersama oleh Craig Calhoun dan Jonathan VanAntwerpen; Oxford Univ Press 2011). Dia menjabat sebagai editor umum buku panduan Oxford University Press tentang agama secara online, dan komentarnya tentang isu-isu kontemporer tentang agama dan politik global muncul di The Huffington Post, The Globalist, Religion Dispatches, The Immanent Frame, dan YaleGlobal Online, dan di BBC, CNN, dan media berita NPR.

Jabatan saat ini sebagai profesor dalam bidang Sosiologi (sejak 1993), Global Studies (sejak 1998), dan Religious Studies (sejak 2002) bersama Orfalea Center for Global \& International Studies (sejak 2005). Jabatan sebelumnya sebagai direktur pada Orfalea Center for Global \& International Studies (2005-2015), direktur pada Global \& International 
Studies Program (1995-2005) University of California, Santa Barbara, ketua pada Pacific Rim Research Program, Univ of California system (1994-1997), dekan pada School of Hawai'ian, Asian and Pacific Studies, dan profesor di bidang Religion and Political Science, University of Hawai'i (1989-93), koordinator dan profesor afiliasi pada Program Studi Agama Universitas of California, Berkeley (1974-1989), profesor dan direktur pada Office of Programs in Comparative Religion, Graduate Theological Union, Berkeley (1974-89) (Juergensmeyer, 2015).

Melihat begitu banyaknya karya Juergensmeyer utamanya tentang studi agama antiglobal, tidak salah kiranya apabila karya-karya tersebut diapresiasi dan dikaji ulang sehingga dapat diketahui posisi agama dalam pusaran globalisasi.

INDIKATOR

AGAMA

\section{ANTIGLOBALISME}

Ada beberapa indikator yang dipakai Juergensmeyer untuk mencari titik temu atas pertanyaan apakah modernitas Barat itu selalu jahat dan modernitas atau postmodernitas itu sebanding dengan globalisasi?

\section{Penolakan Agama pada Globalisasi}

Pertama, pada sekitar abad 19-20 M, globalisasi ekonomi dan budaya sering dianggap sebagai perpanjangan dari kolonialisme. Kemerdekaan politik tidak berarti pembebasan terhadap kekuatan kolonial Eropa dan Amerika. Akulturasi sistem ekonomi dan ikatan budaya global menyebar di Afrika, Asia, Timur Tengah Timur, dan masyarakat Amerika Latin ke Amerika Serikat dan Eropa.

Kedua, mulai tahun 1990 hubungan berbagai negara mulai retak, ekonomi pasar global melemahkan ekonomi nasional, militer dan tentara patroli AS di perbatasan Pakta Pertahanan Atlantik Utara (NATO) dikurangi, runtuhnya Uni Soviet dan postkolonial, tampaknya membuka pintu pembentukan negara-bangsa berbasis sekuler, seperti Yugoslavia. Juergensmeyer memandang, ketika ideologi nasionalisme sekuler mulai runtuh, negara pasti berantakan. Juergensmeyer mengutip pandangan Habermas bahwa hal ini terjadi karena sekularisme diangkut ke berbagai negara sebagai “proyek modernitas” (Habermas, 1987: 148). Walaupun pendapat ini dianggap usang, Juergensmeyer seakan memperkuat pandangannya bahwa dalam dunia yang multikultural berbagai pandangan modernitas berada dalam 
persaingan dan konsep universalitas nasionalisme sekuler menjadi bahan perdebatan yang hangat (Juergensmeyer, 2005: 137).

Tantangan globalisasi sendiri terhadap nasionalisme bervariasi, karena globalisasi merupakan multifaset termasuk di dalamnya, global tidak hanya menjangkau bisnis transnasional tetapi juga tenaga kerja yang mereka pasok, mata uang, dan instrumen keuangan. Lebih luas juga mengacu pada perluasan planet media dan komunikasi teknologi budaya, popularitas, dan masalah lingkungan.

Ketiga, gerakan nasionalisme etnis dan agama telah menguat di negara-negara yang para pemimpinnya merasa dieksploitasi oleh ekonomi global, seperti di Iran dan Mesir. Pergeseran global dalam kekuatan ekonomi dan politik yang terjadi setelah pecahnya Uni Soviet dan ambruknya ekonomi Asia, Jepang dan lainnya dalam 15 tahun lalu memiliki dampak sosial yang signifikan.

Pergeseran ini menyebabkan krisis pada tujuan nasional di negaranegara kurang berkembang. Pemimpin India Jawaharlal Nehru, Mesir Gamal Abdel Nasser, dan Iran Syah Reza Pahlevi pernah mencoba membentuk negara versi mereka sendiri, ala Amerika atau persilangan antara Amerika dan Uni Soviet. Tapi generasi baru pascakolonial tidak percaya lagi pada westernisasi Nehru, Nasser, atau Syah. Sebaliknya, keempat, generasi ini ingin menggantinya dengan legitimasi negara mereka sendiri, nilai-nilai tradisional di ruang publik dan membangun identitas nasional berdasarkan budaya asli (Juergensmeyer, 2005: 137). Keinginan ini semakin menguat ketika mereka mengamati serangan media global dari musik Barat, video, dan film-film televisi, yang mengancam bentuk-bentuk ekspresi budaya lokal dan tradisional. Kelima, dalam kasus lain munculnya masyarakat multikultural melalui diaspora global bangsa dan budaya dan kontrol militer politik global dalam “tatanan dunia baru”, menimbulkan ketakutan. Ketakutan inilah yang dimanfaatkan oleh aktivis Islam Bin Laden, televisi al Jazeera, maupun media populer di dunia Islam untuk menggambarkan respon militer Amerika atas serangan 11/9 sebagai perang salib, bukan aksi kemarahan korban penyerangan.

Pada sebagian dunia Muslim, pasca 11/9 koalisi Amerika terhadap terorisme dilihat sebagai alasan untuk memperluas jangkauan global Amerika. Invasi Amerika atas Irak pada tahun 
2003 tampaknya untuk mengonfirmasi ketakutan terburuk mereka. Mungkin mengejutkan, gambaran peran jahat Amerika dalam menciptakan tatanan dunia baru globalisasi, bahkan di beberapa kalangan Barat sendiri. Di Amerika, misalnya, gerakan identitas Kristen dan organisasi milisi Kristen memiliki kekhawatiran yang besar terhadap konspirasi global yang melibatkan politisi liberal Amerika dan PBB. Di Jepang mirip teori konspirasi gerakan dari Aum Shinrikyo dalam memprediksi bencana Perang Dunia III, mereka diserang dengan gas saraf di kereta bawah tanah Tokyo saat demontrasi.

$$
\text { Dalam pandangan }
$$

Juergensmeyer, gagasan tentang "tatanan dunia baru” sebagai kontrol global terlalu mengada-ada. Meskipun integrasi masyarakat, komunikasi antara masyarakat yang berbeda, dan globalisasi budaya telah membawa dunia lebih dekat secara bersamaan, namun tidak mungkin merancang tren global pada masyarakat lokal dan identitas nasional secara radikal. Dalam pandangan tren Pencerahan, masyarakat di daerah tertentu secara alami terkait dalam spesifikasi negara-bangsa, dan dalam masyarakat multikultural itu sulit mengatakan bagaimana seharusnya mendefinisikan “orang” dalam sebuah bangsa tertentu. Di sinilah agama dan etnis dituntut untuk mendefinisikan masyarakat umum.

Memudarnya negara-bangsa dan kekecewaan pada bentuk-bentuk nasionalisme sekuler, menghasilkan peluang baru berbasis budaya politik dan kebutuhan akan identitas politik secara tradisional melalui ide kebangsaan. Dengan demikian agama, etnis, dan budaya tradisional menjadi sumber identifikasi nasional dan terkadang transnasional.

\section{Karakter Revolusione}

\section{Antiglobalisasi}

Dalam iklim politik kontemporer, setelah hubungan sekuler dapat diungkap, mereka menawarkan ideologi kontemporer yang memenuhi kebutuhan sosial dan politik masa kini yang budaya asli dapat memberikan dasar bagi ideologi politik baru dengan menghidupkan kembali negara-bangsa. Gerakan ini sering konfrontatif dan kadang-kadang menggunakan kekerasan. Mereka menolak intervensi dari luar ideologi mereka, tidak toleran, menjadi kaki tangan adat budaya dan penegakan batas-batas sosial tradisional. Barat yang sekuler sering menganggap modernisme sebagai musuh, musuh yang paling mudah disimbolkan oleh Amerika. 
Karena itu gerakan ini sangat membenci Amerika apalagi Amerika memang tidak menjelaskan nilai-nilai sekuler transnasional dan manfaatnya. Misalnya, Amerika memiliki kepentingan ekonomi dan politik pribadi dalam menopang stabilitas rezim di seluruh dunia. Hal ini sering menempatkan Amerika pada posisi sebagai pembela pemerintah sekuler otokratis, pendukung ekonomi global dan budaya sekuler. Di dunia yang penduduk desanya di pelosok terpencil di dunia, semakin memiliki akses ke MTV, film-film Hollywood, dan internet, gambar yang tidak pantas secara budaya dan nilai-nilai yang telah diproyeksikan secara global, sering kali dialamatkan pada Amerika yang itu sangat merendahkan Amerika sendiri. Itulah ketepatan gambaran kelompok etnis dan agama terhadap Amerika, terutama gagasan perang kosmiknya. Dalam skenario Amerika, kelompok etnis dan agama bersaing menjadi musuh dan kambing hitam, dan negara sekuler menjadi musuh agama, hingga Ayatollah Khomeini, menggambarkan Amerika sebagai Setan Besar, dan semua masalah Iran merupakan karya Amerika (Juergensmeyer, 2005: 140). Dengan ini berarti permusuhan tidak hanya masalah politik dan ekonomi tetapi juga budaya dan intelektual. Kebencian ini ditanamkan oleh para pengkhotbah di institusi pengajaran agama, perguruan tinggi, lembaga pendidikan pemerintah, media lokal, dan orientalis yang bekerja dalam pelayanan negara-negara imperialis. Kekuatan ini hanya dapat diimbangi dengan kekuatan adikodratinya.

\section{Agenda Global Antiglobalis}

Ketakutan kelompok agama radikal pada globalisasi termasuk ekonomi global dan nilai-nilai budaya sekuler akan melemahkan basis legitimasi mereka dari identitas politik dan kekuasaan. Padahal, hubungan yang disandang oleh agama dengan globalisasi sesungguhnya memberikan landasan intelektual atau dibentuk oleh globalisme yang sangat bervariasi satu sama lain berdasarkan konteks nasional dan local (Turner, 2013: 833). Walaupun di sisi lain, globalisasi disikapi secara netral atau globalisasi justru digunakan untuk tujuan mereka. Mereka memiliki agenda global sendiri, transnasional alternatif dengan sistem negara-bangsa modern. Perang teroris semakin dilancarkan pada skala internasional dan transnasional. Jaringan Al-Qaeda internasional berafiliasi pada Jamaah Islamiyah. Serangan-serangan di seluruh dunia menurut Juergensmeyer dapat dilihat sebagai pertempuran dalam 
"Perang Dingin baru”, atau lebih menakutkan lagi, bentrokan “peradaban”, seperti disebutkan Samuel Huntington (1996). Di balik citra benturan budaya dan peradaban ada visi tertentu tentang realitas sosial yang melibatkan serangkaian lingkaran konsentris. Bagian terkecil merupakan keluarga dan klan, selanjutnya kelompok etnis dan bangsa yang terbesar, dan secara implisit yang paling penting, merupakan agama. Agama juga terkait erat dengan politik. Bentuk-bentuk politik agama lebih dari sekedar nasionalis, Hasil dari proses ini merupakan bentuk global yang secara radikal berbeda dari versi sekuler globalisasi. Itulah konfrontasikonfrontasi ideologi dalam skala global (Juergensmeyer, 2005: 143).

\section{Masa Depan Agama Antiglobalisme}

Ambivalensi gerakan keagamaan radikal dengan globalisasi menumbuhkan dimensi transnasional sendiri. Ada tiga masa depan untuk revisi radikal di dunia global: pertama, politik agama mengabaikan globalisasi, kedua, mereka tetap dalam posisinya yang antiglobal, dan ketiga, membayangkan mereka sendiri bermasa depan transnasional.

\section{a. Negara Agama Nonglobalisasi Baru}

Tujuan dari beberapa aktivis keagamaan yakni membangkitan kembali negara-bangsa yang terhindar dari efek globalisasi. Munculnya negara agama baru cenderung menjadikan mereka sebagai isolasionis, seperti Iran. Tidak sampai sekitar 20 tahun, gerakan baru politik Islam moderat ini mendorong para pemimpin Iran untuk pindah dari isolasi internasional mereka. Begitu pula Osama bin Laden dan jaringan al-Qaeda itu menyebabkan mereka tersapu dalam perang badai Amerika. Gerakan lain dari nasionalisme agama belum cukup sebagai isolasionis yang ekstrim. Di India, ketika Hindu nasionalis Bharatiya di Janata (BJP, Partai Rakyat India) digulingkan oleh Partai Kongres di 2004. Namun demikian BJP tetap dipertahankan karena memiliki senjata nuklir dan pimpinan BJP Menteri Atal Bihari Vajpayee, merupakan orang yang paling berpengalaman di negara itu sebagai politisi. Jika gerakan-gerakan lain dari nasionalisme agama dan etnis berkuasa, akankah mereka bisa berperilaku seperti Taliban atau BJP? Pengamat memantau perkembangan di Pakistan, Mesir, Aljazair, dan tempat lain bahwa tandatanda sentimen antiglobal seharusnya memiliki kekuatan besar politik agama 
di daerah tersebut yang mendukung pembentukan negara agama. Ketika Abdurrahman Wahid, seorang ulama Muslim yang mengalahkan Megawati di tahun 1999, Wahid sebagai muslim moderat dan toleran, berkomitmen untuk membawa Indonesia menjadi masyarakat dunia dan pasar ekonomi global.

\section{b. Gerilya Antiglobalisme}

Di daerah lain di dunia ini bukan penciptaan negara agama baru yang menjadi masalah tetapi kerusakan negara sekuler lama tanpa alternatif politik yang jelas. Dalam beberapa kasus, aktivis agama dan etnis telah memberikan kontribusi terhadap kondisi ini. Di bekas negara Yugoslavia, misalnya, pertumpahan darah di Bosnia dan Kosovo disebabkan oleh runtuhnya tatanan sipil sebagai upaya untuk menciptakan daerah etnis dan agama baru. Di Irak, pemberontak Islam menentang pendudukan Amerika yang mereka anggap bersikeras membentuk masyarakat dunia homogen dan negara polisi global. Serangan teroris terhadap gedung federal Oklahoma City dan serangan lain di seluruh dunia merupakan tindakan yang mungkin dianggap Gerilya antiglobalism. Gerilya terbesar antiglobalis menjadi jaringan jihad yang terkait dengan Osama bin
Laden pemimpin organisasi Al-Qaeda. Dendam terhadap globalisasi sekuler yang dipimpin oleh Amerika dan Barat sekuler telah menyebabkan pemboman kedutaan besar Amerika di Afrika pada tahun 1998 dan USS Cole di Yaman pada tahun 2000, peristiwa September, 2001, serangan terhadap klub malam di Bali 2002, pemboman kereta Madrid pada tahun 2004 dan sejumlah serangan terkait dengan pendudukan Amerika terhadap Irak. Tujuan tindakan teroris yang dramatis menunjukkan kepada masyarakat Muslim bahwa ada perang global yang luas yang dilakukan oleh Amerika dengan bentuk globalisasi dengan kekuatan jahat, sementara kekuatan baik diidentifikasi sebagai seorang Muslim transnasional yang dipimpin oleh tokoh-tokoh heroik seperti Osama bin Laden.

\section{c. Aliansi Transnasional}

Luasnya jangkauan gerakan jihad juga memberikan contoh dimensi lain dari aktivis keagamaan kontemporer terhadap transnasionalitas mereka. Anggota al-Qaeda yang berasal dari Aljazair, Mesir, Palestina, dan Pakistan, serta asal bin Laden, Arab Saudi banyak diantaranya yang ditempa menjadi kekuatan tempur multinasional dalam kancah perang Afghanistan melawan Soviet. Tujuan politiknya untuk 
menggambarkan adanya kerajaan Islam transnasional. Menurut salah satu teori politik Islam global yang beredar di Mesir pada 1980 dan 1990, gerakan lokal politik Muslim dimaksudkan sebagai langkah pertama dalam menciptakan entitas politik Islam yang lebih besar dari negara-negara Muslim yang berdekatan. Dalam nasionalisme, agama akan menjadi prekursor transnasionalisme agama. Aktivis agama dan etnis telah dikembangkan ke diaspora global budaya dan masyarakat, dan Osama bin Laden mewakili transnationalitas itu. Anggota gerakannya telah menyusup melalui komunitas Muslim imigran dari Jerman, Belgia, Spanyol, Inggris, Kanada, dan Amerika Serikat. Komunikasi internet yang cepat memungkinkan anggota masyarakat etnis dan agama untuk mempertahankan hubungan erat dalam disparitas geografis. Situs Website yang semakin terbuka dan dilindungi sandi telah menempatkan mereka dalam komunitas cyber militan religius di seluruh dunia. Separatis Sikh India, Sinhala dan Tamil Sri Lanka memberikan dukungan dana dan moral untuk jaringannya.

5. Modernitas, Identitas, Power, dan Globalisasi
Masa depan antiglobalism agama memiliki hubungan paradoks antara bentuk tertentu globalisasi dan kebangkitan aktivisme religius. Munculnya lembaga-lembaga politik dan ekonomi transnasional meningkatkan kebutuhan pada identitas lokal. Masalah penting di era globalisasi merupakan identitas dan kontrol sosial. Keduanya berkaitan dan kehilangan itu merupakan satu ketidakberdayaan. Pada saat yang sama, apa yang telah dirasakan sebagai hilangnya iman dalam nasionalisme sekuler, dialami sebagai hilangnya badan serta identitas. Untuk alasan ini pernyataan dari bentuk-bentuk identitas agama tradisional terkait dengan upaya untuk merebut kembali kekuatan pribadi dan budaya. Terorisme yang telah dilakukan 11/9 2001 dapat dilihat sebagai upaya tragis untuk mendapatkan kembali kontrol sosial dalam tatanan global melalui tindak kekerasan. Oleh karena itu, visi tatanan moral keagamaan akan terus tampil meskipun sering mengganggu modernitas, identitas, dan dunia global.

\section{KESIMPULAN}

Globalisasi memberikan dampak yang negatif dan positif terhadap kehidupan beragama. Globalisasi telah menimbulkan semakin tingginya 
intensitas pergulatan antara nilai-nilai ekonomi, politik, budaya, dan agama. Sistem nilai yang selama ini digunakan sebagai acuan oleh masyarakat lokal tidak jarang mengalami perubahan karena pengaruh nilai-nilai global, terutama dengan adanya kemajuan teknologi informasi mempercepat proses perubahan tersebut. Perubahan tersebut adakalanya disikapi gerakan keagamaan dengan mengenyampingkan globalisme, menyapu bersih globalisme, atau menerima globalisasi dengan syarat. Hanya saja, dengan merajanya globalisasi, gerakan keagamaan sering terjebak pada tindak kekerasan dan gerakan antiglobalisasi lain yang berdampak negatif.

Juergensmeyer dalam tulisannya ini telah mencoba membantu Muslim mengurai benang kusut pertikaian yang menimpa gerakan agama antiglobal dan pendukung globalisasi (Amerika). Identitas diri dan kontrol sosial sangat penting diletakkan sebagai dasar menyikapi kondisi dunia yang serba global yang mungkin tidak disadari oleh gerakan agama itu sendiri. Upaya selanjutnya, mengemas agama dalam tampilan yang tidak terkotak-kotak, lebih humanis dan tidak menyeramkan di mata muslim, non-muslim, Amerika, bahkan pada masyarakat global.

\section{DAFTAR PUSTAKA}

Habermas, Jurgen. 1987. "Modernity: An Incomplete Project". Interpretive Social Science: A Second Look. Hal. 141-156. Berkeley: University of California Press.

Huntington, Samuel P. 1996. The Clash of Civilizations and the Remaking of World Order. New York: Simon and Schuster.

Juergensmeyer, Mark. 2003. Global Religions: An Introduction. Oxford: Oxford University Press.

Juergensmeyer, Mark. 2005. "Religious Antiglobalism”. Religion in Global Civil Society. Hal. 135-148. New York: Oxford University Press.

Larry A. Samovar, dkk. 2009. Communication Between Cultures. Wadsworth: Cengage Learning.

The Departement of Global Studies Santa Barbara. 2016. Curriculum Vitae Mark Juergensmeyer. http://www.juergensmeyer.org/. California.

Tim Penyusun Kamus Pusat Bahasa. 2001. Kamus Besar Bahasa Indonesia, Edisi ketiga Jakarta: Balai Pustaka.

Turner, Bryan S. 2013. Sosiologi Agama. Yogyakarta: Pustaka Pelajar 